Rehbinder/Stewart, Environmental Protection Policy

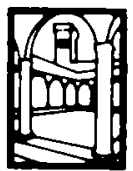

European University Institute 



\section{Environmental Protection Policy}

Legal Integration in the United States and the European Community

by

Eckard Rehbinder and Richard Stewart

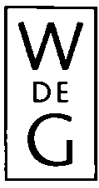

1988

Walter de Gruyter · New York · Berlin 
This is a paperback version of a book originally published as volume 2 of Integration Through Law

Europe and the American Federal Experience

A Series under the General Editorship of Mauro Cappelletti, Monica Seccombe, Joseph Weiler in: European University Institute Series A, 2.2

Rehbinder, Eckard.

Environmental protection policy.

“Originally published as volume 2 of Integration through law:

Europe and the American federal experience"-

Verso t.p.

Includes index.

1. Environmental law-European Economic community countries. 2. Environmental law-United States.

I. Stewart, Richard B. II. Title.

KJE6242.R44 $1988 \quad 344.4^{\prime} 046$

ISBN 0-89925-396-2 (pbk.) $\quad 344.0446$

88-3612

(C) 1988 by Walter de Gruyter \& Co., Berlin.

All rights reserved, including those of translation into foreign languages. No part of this book may be reproduced in any form - by photoprint, microfilm, or any other means nor transmitted nor translated into a machine language without written permission from the publisher.

Cover Design: K. Lothar Hildebrand, Berlin. - Setting: Satz-Rechen-Zentrum, Berlin. Printed in the United States of America 